\title{
PENURUNAN BOD DAN COD LIMBAH CAIR INDUSTRI TEKSTIL DI KABUPATEN PEKALONGAN DENGAN METODE MULTI SOIL LAYERING
}

\author{
Irmanto, Suyata \\ Program Studi Kimia, Jurusan MIPA \\ Fakultas Sains dan Teknik, Universitas Jenderal Soedirman, Purwokerto
}

\begin{abstract}
Multi Soil Layering (MSL) system is a method of wastewater treatment that increase the soils function to purify wastewater. In the construction of MSL, soils mixed with the charcoal and then filled into the box of size $50 \times 14 \times 50 \mathrm{~cm}$ in layers structured like brick pattern. The aims of this research are to determine the concentration of BOD and COD on textile industrial wastewater before and after the process by MSL method. It also determines the optimal loading rate of wastewater on the MSL system, and then it can determine the efficiency of MSL system on reducing the concentration of BOD and COD on textile industrial wastewater. The method which used in this research is an experimental method. The wastewater on the MSL system is loaded on the loading rate variety: 160, $320,480,640$, and $800 \mathrm{~L} \mathrm{~m}^{-2}$ day $^{-1}$. The efficiency of MSL system to removing BOD and COD on textile industrial wastewater are determined on optimal loading rate. The research gave result that MSL method could remove BOD and COD on textile industrial wastewater on the optimal loading rate $320 \mathrm{~L} \mathrm{~m}^{-2}$ day $^{-1}$. The efficiency of MSL system in removing BOD and COD on textile industrial wastewater are 96.52 and $80.87 \%$ respectively. This indicated that the method MSL serve the purpose of effective alternative method in processing of liquid waste textile industry.
\end{abstract}

Keywords : MSL method, textile, wastewater, BOD, COD

\section{PENDAHULUAN}

Salah satu sumber pendapatan daerah Pekalongan berasal dari industri tekstil. Keberadaan industri tekstil ini disamping mempunyai dampak positif terhadap daerah juga mempunyai dampak negatif yaitu timbulnya pencemaran lingkungan. Pencemaran lingkungan disebabkan oleh kualitas limbah cair yang dibuang ke badan perairan belum memenuhi baku mutu sesuai dengan SK Menteri KLH No. Kep. 03 / MENKLH / 1991.

Limbah cair industri tekstil terutama dihasilkan dari proses pewarnaan (dyeing), pengecapan (printing), dan finishing. Pada umumnya bahan-bahan kimia yang digunakan dalam proses tersebut terdiri dari senyawa organik. Banyaknya senyawa organik yang larut menyebabkan tingginya nilai BOD (Biochemical Oxygen Demand ) dan COD ( Chemical Oxygen Demand ) limbah cair industri tekstil.

Berbagai teknik pengolahan limbah cair telah dikembangkan seperti adsorpsi dengan karbon aktif, oksidasi kimiawi, digesti biologis. Masing-masing teknik ini penggunaannya masih terbatas dan kurang menguntungkan, sebagai contoh, karbon aktif hanya melibatkan adsorpsi polutan tanpa dekomposisi. Oksidasi kimia tidak dapat memineralisasi semua senyawa organik dan hanya cocok untuk menghilangkan polutan dengan konsentrasi tinggi. Pengolahan secara biologis memiliki kelemahan yaitu 
kecepatan reaksi lambat, pembuangan lumpur aktif yang sulit, $\mathrm{pH}$ dan temperatur harus dikontrol. Suatu teknik pengolahan limbah organik yang lebih efektif, efisien, mudah, dan murah perlu dikembangkan yaitu metode Multi Soil Layering (MSL).

Sistem MSL merupakan suatu sistem yang menggunakan tanah andisol, zeolit, kerikil (gravels), dan arang tempurung kelapa sebagai sumber karbon serta menggunakan pipa aerasi sebagai sumber oksigen. Lapisan tanah dan zeolit disusun dengan pola seperti batu bata untuk mencegah terjadinya penyumbatan dan pembentukan lapisan impermeable (Wakatsuki et al., 1993).

Bahan-bahan yang diperlukan untuk membuat sistem ini tersedia secara lokal sehingga disamping teknik ini murah juga memanfaatkan sumberdaya alam lokal Kabupaten Banyumas. Zeolit diperoleh dari Kecamatan Lumbir, sedangkan tanah andisol dari Bukit Cendana Baturraden.

Sistem MSL dikembangkan untuk meningkatkan fungsi tanah dalam pengolahan limbah cair biogenik sebelum dilepas ke badan perairan. Proses biodegradasi komponen air limbah dalam sistem MSL berlangsung melalui bantuan bakteri-bakteri di bawah kondisi aerobik maupun anaerobik. Zona aerobik terjadi pada lapisan kerikil dan zeolit serta antar muka antara lapisan zeolit dan lapisan tanah. Zona anaerobik terjadi pada lapisan campuran tanah dengan arang tempurung kelapa.

Berdasarkan hasil penelitian Wakatsuki et al. (2001), metode MSL dapat menurunkan BOD dan COD Sungai Uya di Kepulauan Oki, Jepang sampai $90 \%$. Luanmanee et al. (2000) menggunakan metode MSL untuk pengolahan limbah domestik dari kafetaria dan toilet Universitas Kasetsart, Thailand dan dapat menurunkan BOD sebesar 98,8\% dan COD sebesar 93,6\%. Menurut Wakatsuki et al. (1993), sistem
MSL efektif digunakan untuk pengolahan limbah selama 12,8 tahun. Sistem MSL kemungkin lebih pendek atau lebih panjang dibandingkan perkiraan, tergantung pada mutu limbah, kandungan dan jenis dari material organik, temperatur dan manajemen dari sistem tersebut.

Mengingat kandungan limbah cair industri tekstil atau sebagian besar adalah bahan organik dapat terurai (degradable organic matter), maka perlu dilakukan penelitian untuk mengembangkan metode MSL dalam pengolahan limbah cair industri tekstil, terutama mempelajari kemampuan sistem MSL untuk menurunkan BOD dan COD.

Metode Multi Soil Layering (MSL) telah digunakan untuk pengolahan limbah cair domestik dan air sungai terpolusi. Metode ini akan dikembangkan untuk pengolahan limbah cair industri tekstil.

Adapun yang menjadi masalah dalam penelitian ini adalah: Berapakah kecepatan pengisian (loading) optimum air limbah ke dalam sistem MSL untuk memperoleh persentase penurunan BOD dan COD yang optimum?. Berapa persenkah penurunan BOD dan COD limbah cair industri tekstil setelah dilakukan pengolahan dengan sistem MSL?

\section{METODE PENELITIAN Bahan dan Alat.}

Alat- alat yang digunakan dalam penelitian ini adalah: instrumen MSL, botol winkler, alat-alat gelas, kertas saring.

Bahan-bahan kimia yang digunakan adalah: $\mathrm{MgSO}_{4}$, alkali azida, $\mathrm{MnSO}_{4}$, $\mathrm{H}_{2} \mathrm{SO}_{4}$ pekat, $\mathrm{HgSO}_{4}, \mathrm{KMnO}_{4}, \mathrm{KI}$, $\mathrm{Na}_{2} \mathrm{~S}_{2} \mathrm{O}_{3}, \mathrm{Na}_{2} \mathrm{CO}_{3}, \mathrm{KH}_{2} \mathrm{PO}_{4}, \mathrm{Na}_{2} \mathrm{HPO}_{4}$, $\mathrm{NH}_{4} \mathrm{Cl}$, dan aquades. 


\section{Prosedur Kerja}

\section{Pembuatan Sistem MSL}

Instrumen sistem MSL dibuat dengan konstruksi seperti dapat dilihat pada Gambar 1. Bak akrilik dengan ukuran dimensi dalam $(50 \mathrm{~cm}$ x $15 \mathrm{~cm} \mathrm{x}$ $50 \mathrm{~cm}$ ) disiapkan. Dasar bak diisi dengan batu kerikil dengan ketinggian $4 \mathrm{~cm}$, lalu seluruh permukaan batu kerikil ditutup dengan net. Lapisan kedua berikutnya diisi zeolit (berdiameter 2-3 $\mathrm{mm}$ ) dengan ketinggian $4 \mathrm{~cm}$. Empat buah bingkai triplek masing-masing dengan dimensi dalam $(4 \mathrm{~cm} \times 9 \mathrm{~cm}$ x $15 \mathrm{~cm})$ dipasang sejajar pada jarak masing-masing $3 \mathrm{~cm}$.

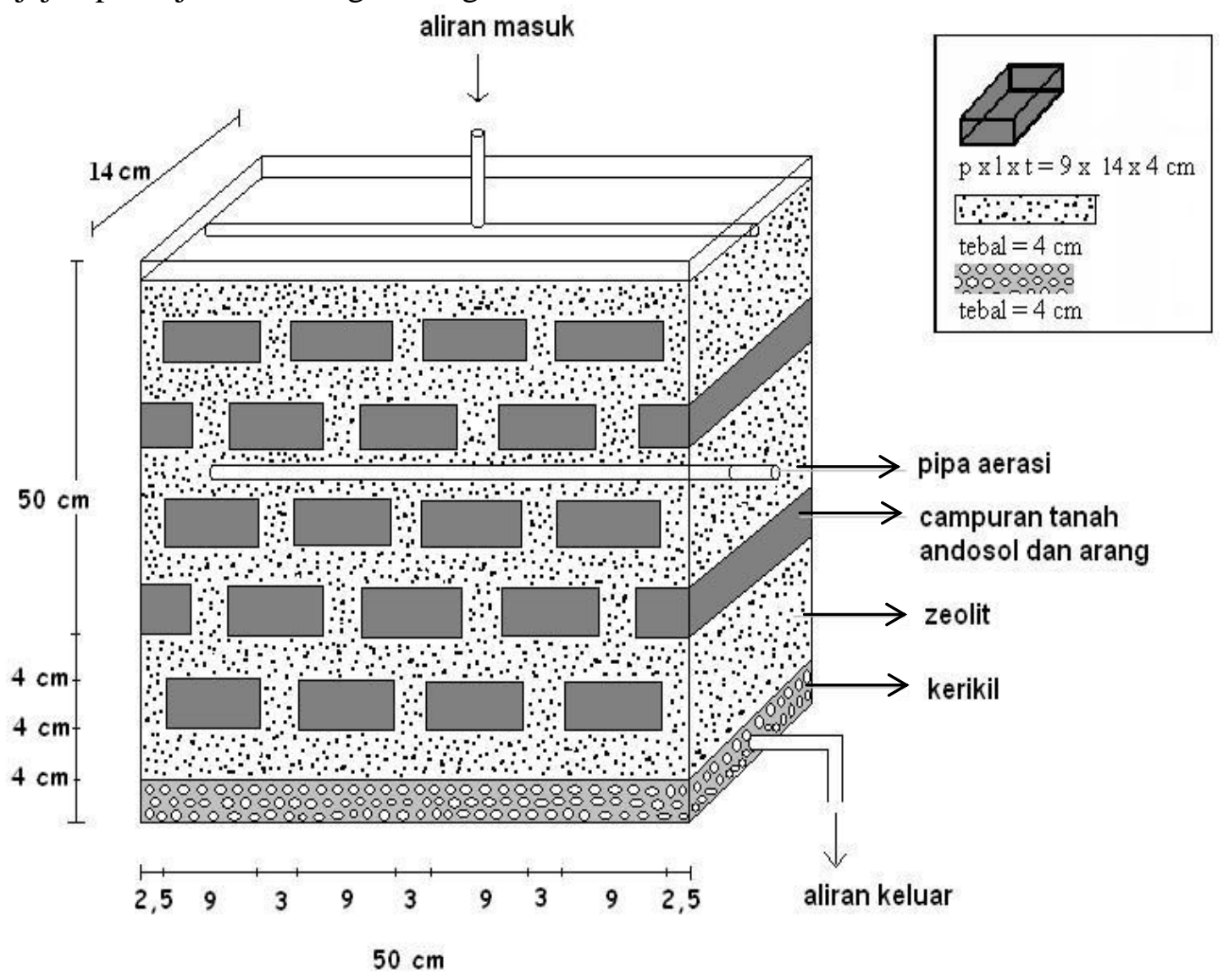

Ke dalam bingkai triplek dialas dengan plastik net halus yang dapat membungkus blok-blok lapisan campuran tanah. Campuran tanah dan arang tempurung kelapa dengan perbandingan $1: 1$ diisi ke dalam bingkai triplek, lalu dipadatkan. Bingkai triplek diangkat dan lapisan selanjutnya diisi dengan zeolit setinggi 4 $\mathrm{cm}$. Lapisan-lapisan lain diisi dengan cara yang sama sampai membentuk lima lapisan blok-blok tanah. Antara lapisan ke 3 dan 4 dipasang pipa aerasi (diameter $1,5 \mathrm{~cm}$ ) dengan jarak antar lubang aerasi $5 \mathrm{~cm}$ dan ukuran diameter lubang 0,5 $\mathrm{mm}$.

Gambar 1. Instrumen Multi Soil Layering

\section{Penentuan Kecepatan Pengisian Air Limbah ke Dalam Sistem MSL}

1. Penentuan nilai BOD dan COD dalam limbah cair industri tekstil sebelum diolah (treatment) dengan sistem MSL. (a) masing-masing parameter dianalisis sesuai dengan metode analisis.

(b) pengukuran dilakukan secara triplo.

2. Air limbah diisikan ke dalam sistem MSL selama 24 jam per hari pada 
berbagai variasi kecepatan pengisian $\left(160,320,480,640,800 \mathrm{Lm}^{-2} \mathrm{~h}^{-1}\right)$.

3. Penentuan nilai BOD dan COD dalam limbah cair industri tekstil pada berbagai variasi kecepatan pengisian setelah diolah (treatment) dengan sistem MSL.
(a)masing-masing parameter dianalisis sesuai dengan metode analisis
(b) pengukuran dilakukan secara triplo

4. Perhitungan persentase penurunan BOD dan COD dalam limbah cair industri tekstil pada berbagai variasi kecepatan pengisian.

\section{Penentuan Efisiensi Sistem MSL untuk Menurunkan BOD Dan COD Limbah Cair Industri Tekstil.}

1. Pada kecepatan pengisian optimum dan dengan cara yang sama ditentukan persentase penurunan BOD dan COD.

2. Penyamplingan dilakukan seminggu sekali selama 6 bulan.

\section{Metode Analisis}

Penentuan BOD (APHA, 1995)

Penentuan BOD dilakukan dengan menggunakan metode titrasi Winkler, dimana kadar BOD dihitung dengan rumus : $\mathrm{BOD}=\mathrm{DO}_{(0)}-\mathrm{DO}_{(5)}$

\section{Penentuan $\mathrm{DO}_{(0)}$}

Dipipet $50 \mathrm{~mL}$ sampel, dimasukkan ke dalam labu ukur $1000 \mathrm{~mL}$ ditambahkan masing-masing $1 \mathrm{~mL}$ buffer posfat, $\mathrm{MgSO}_{4}, \mathrm{CaCl}_{2}$ dan $\mathrm{FeCl}_{3}$ dan diencerkan dengan akuades sampai tanda batas. Dipindahkan ke beker gelas 1000 $\mathrm{mL}$ lalu diaerasi selama 15 menit. Dimasukkan ke dalam botol winkler dan ditutup, tambahkan masing-masing $1 \mathrm{~mL}$ alkali azida dan $\mathrm{MnSO}_{4} 10 \%(\mathrm{~b} / \mathrm{v})$, tutup lalu kocok dengan membalik-balikan botol winkler. Dibiarkan selama 10 menit lalu dipindahkan ke erlenmeyer. $\begin{array}{llll}\text { Ditambahkan } 1 & \mathrm{~mL} & \mathrm{H}_{2} \mathrm{SO}_{4} & \text { pekat, }\end{array}$ dikocok dan dititrasi dengan tiosulfat hingga kuning pucat. Ditambahkan beberapa tetes amilum $1 \%(\mathrm{~b} / \mathrm{v})$ kemudian titrasi dilanjutkan sampai warna biru tepat hilang.

\section{Penentuan DO (5)}

Sampel yang telah diaerasi pada pengerjaan $\mathrm{DO}_{(0)}$ dimasukkan ke dalam botol Winkler dan ditutup rapat tanpa adanya udara dan disimpan 5 hari. Kemudian dititrasi dengan cara yang sama pada penetuan $\mathrm{DO}_{(0)}$. Kadar oksigen terlarut dapat dihitung dengan rumus :

$$
\begin{aligned}
& \text { Kadar } \mathrm{O}_{2}(\mathrm{ppm})=\frac{(\mathrm{mL} \times \mathrm{N}) \text { pentiter } \times 8000}{\mathrm{~mL} \text { sampel }-2} \\
& \mathrm{DO}=\text { kadar } \mathrm{O}_{2}(\mathrm{ppm}) \times \text { faktor pengenceran }
\end{aligned}
$$

\section{Penentuan COD (APHA, 1995)}

Penentuan COD dilakukan dengan menggunakan metode titrasi iodometri. 5 $\mathrm{mL}$ akuades sebagai blanko dan $5 \mathrm{~mL}$ sampel dimasukkan ke dalam erlenmeyer $250 \mathrm{~mL}$ ditambahkan $2,5 \mathrm{~mL} \mathrm{~K}_{2} \mathrm{Cr}_{2} \mathrm{O}_{7}-$ $\mathrm{HgSO}_{4}$ dan $5 \mathrm{~mL} \mathrm{H}_{2} \mathrm{SO}_{4}-\mathrm{Ag}_{2} \mathrm{SO}_{4}$. Ditutup dengan plastik, lalu dipanaskan selama 2 jam dalam oven pada suhu 150 ${ }^{\circ} \mathrm{C}$, didinginkan dan dibilas bagian tutupnya dengan $2 \mathrm{~mL}$ aquades. Ditambahkan $1 \mathrm{~mL} \mathrm{H}_{2} \mathrm{SO}_{4}$ pekat dan 3 tetes indikator feroin. Kemudian dititrasi dengan larutan standar ferro ammonium sulfat $0,025 \mathrm{~N}$ sampai berwarna merah coklat. Kadar COD dapat dihitung dengan rumus :

$$
\begin{aligned}
\text { Kadar } \mathrm{COD}(\mathrm{ppm})=\frac{(\mathrm{A}-\mathrm{B}) \times \mathrm{N} \times 8000}{\mathrm{~mL} \text { sampel }} \\
\text { dimana : } \mathrm{A}=\mathrm{mL} \text { pentiter untuk blanko } \\
\mathrm{B}=\mathrm{mL} \text { pentiter untuk sampel } \\
\mathrm{N}=\text { normalitas } \mathrm{Na}_{2} \mathrm{~S}_{2} \mathrm{O}_{3}
\end{aligned}
$$




\section{Analisis Data}

Data yang dikumpulkan adalah nilai BOD dan COD limbah cair tekstil sebelum dan setelah dilakukan pengolahan dengan sistem MSL. Dari data tersebut dihitung persentase penurunan BOD dan COD setelah dilakukan pengolahan dengan sistem MSL. Persentase penurunan dihitung dengan rumus:

$\operatorname{Kadar}(\%)=$ konsentrasi awal - konsentrasi akhir x $100 \%$ konsentrasi awal

\section{HASIL DAN PEMBAHASAN}

\section{Penentuan kecepatan pengisian} optimum limbah cair industri tekstil pada sistem MSL

Pengisian air limbah ke dalam sistem MSL melalui pipa berlubang yang dibuat dengan diameter 1,5 $\mathrm{mm}$ dan jarak antar lubang $5 \mathrm{~cm}$. Bagian pipa yang berlubang menghadap ke atas dengan tujuan agar distribusi limbah dalam sistem MSL merata (Wakatsuki et al., 2001). Kecepatan pengisian limbah cair yang digunakan dalam penentuan kecepatan pengisian optimum adalah 160 , 320, 480, 640, dan $800 \mathrm{Lm}^{-2}$ hari $^{-1}$. Kecepatan pengisian optimum inilah yang selanjutnya digunakan untuk menentukan efisiensi sistem MSL dalam menurunkan nilai BOD dan COD limbah cair industri tekstil.

Tabel 1. Persentase penurunan BOD dan COD limbah cair industri tekstil pada berbagai variasi kecepatan pengisian

\begin{tabular}{|c|c|c|c|c|c|}
\hline \multirow[t]{2}{*}{ Parameter } & \multicolumn{5}{|c|}{ Kecepatan pengisian $\left(\mathrm{L} \mathrm{m}^{-2}\right.$ hari $\left.^{-1}\right)$} \\
\hline & 160 & 320 & 480 & 640 & 800 \\
\hline \multicolumn{6}{|l|}{ BOD $\left(\mathrm{mg} \mathrm{L}^{-1}\right)$} \\
\hline Sebelum diolah & $1.081,63$ & $1.387,76$ & $1.316,33$ & $1.051,02$ & $1.071,43$ \\
\hline Setelah diolah & 122,45 & 40,82 & 122,45 & 214,29 & 326,53 \\
\hline Penurunan $(\%)$ & 88,68 & 97,06 & 90,70 & 79,61 & 69,52 \\
\hline \multicolumn{6}{|l|}{$\operatorname{COD}\left(\mathrm{mg} \mathrm{L}^{-1}\right)$} \\
\hline Sebelum diolah & $2.850,00$ & $2.790,00$ & $2.920,00$ & $2.800,00$ & $2.860,00$ \\
\hline Setelah diolah & 880,00 & 500,00 & $1.180,00$ & 1250,00 & $1.360,00$ \\
\hline Penurunan $(\%)$ & 60,12 & 82,08 & 59,59 & 55,36 & 52,45 \\
\hline
\end{tabular}

Tabel 1 menunjukkan bahwa persentase penurunan nilai BOD dan COD pada kecepatan pengisian 160 dan $320 \mathrm{Lm}^{-2}$ hari $^{-1}$ mengalami peningkatan, sedangkan pada kecepatan pengisian 480 sampai dengan $800 \mathrm{Lm}^{-2}$ hari ${ }^{-1}$ persentase penurunan berkurang, baik untuk BOD maupun COD. Persentase tertinggi terjadi pada kecepatan pengisian $320 \mathrm{Lm}^{-}$ ${ }^{2}$ hari $^{-1}$. Oleh karena itu, $320 \mathrm{Lm}^{-2}$ hari $^{-1}$ dipilih sebagai kecepatan pengisian optimum limbah cair tekstil ke dalam sistem MSL. Berarti pada kecepatan pengisian optimum, mikroorganisme dalam sistem MSL dapat mendekomposisi senyawa organik secara optimal. Menurut Choliq (1992), proses pengolahan bahan organik dalam limbah cair oleh mikroorganisme terdapat dua kejadian yang sangat penting, yaitu :

1. pemakaian oksigen oleh mikroorganisme untuk respirasi, dan

2. pembentukan sel mikroorganisme dengan memanfaatkan zat organik sebagai sumber makanan dan energi.

Proses penguraian tersebut dapat digambarkan sebagai berikut : 
Zat organik $+\mathrm{O}_{2} \stackrel{\text { sel }}{\longrightarrow}$ sel baru $+\mathrm{CO}_{2}+\mathrm{H}_{2} \mathrm{O}$
$\mathrm{Sel}+\mathrm{O}_{2} \longrightarrow \mathrm{CO}_{2}+\mathrm{H}_{2} \mathrm{O}+\mathrm{NH}_{3}$
Seiring dengan penurunan nilai BOD dan COD pada sistem pengolahan limbah cair tekstil dengan menggunakan metode MSL ini diikuti dengan meningkatnya kadar $\mathrm{O}_{2}$ terlarut dalam air limbah olahan. Menurut Tahir et al. (1997), pada kecepatan pengisian 100 $400 \mathrm{~L} \mathrm{~m}^{-2}$ hari $^{-1}$ sistem MSL mempunyai persentase penurunan kadar limbah organik yang paling efektif.

\section{Penentuan Efisiensi Sistem MSL untuk Menurunkan BOD dan COD Limbah Cair Industri Tekstil}

Limbah cair industri tekstil dialirkan ke dalam sistem MSL secara terus-menerus pada kecepatan pengisian optimum dan penyamplingan dilakukan seminggu sekali. Efisiensi sistem MSL merupakan rataan persentase penurunan nilai parameter pada periode penyamplingan (Tabel 2).

Tabel 2. Efisiensi sistem MSL untuk menurunkan BOD dan COD

\begin{tabular}{lccccccc}
\hline Parameter & \multicolumn{3}{c}{ Penurunan nilai (\%) pada periode penyamplingan } & \multirow{2}{*}{ Efisiensi (\%) } \\
\cline { 2 - 6 } & I & II & III & IV & V & VI & \\
\hline BOD & 96,64 & 96,12 & 97,14 & 97,12 & 96,52 & 95,58 & 96,52 \\
COD & 82,14 & 80,47 & 81,16 & 81,12 & 79,93 & 80,41 & 80,87 \\
\hline
\end{tabular}

Tabel 2 menunjukkan bahwa efisiensi sistem MSL untuk menurunkan BOD dan COD adalah 96,52 \% dan 80,87 $\%$. Hal ini menunjukkan bahwa mikroorganisme yang terdapat dalam sistem MSL mampu mendegradasi limbah cair industri tekstil dengan baik. Nilai BOD dan COD limbah cair industri tekstil sebelum diolah menggunakan sistem MSL di atas baku mutu menurut Keputusan Gubernur Kepala Daerah Tingkat I Jawa Tengah Nomor : 660.1/02/1997 dan setelah diolah berada di bawah baku mutu (Tabel 3). Menurut keputusan tersebut antara lain telah ditetapkan bahwa nilai maksimum BOD dan COD, untuk limbah cair industri tekstil adalah 150 ppm untuk BOD dan 300 ppm untuk COD, dengan beban pencemaran maksimum untuk BOD sebesar $6 \mathrm{~kg} / \mathrm{ton}$, untuk COD sebesar 12 $\mathrm{kg} /$ ton dengan debit maksimum $40 \mathrm{~m}^{3} / \mathrm{ton}$ produk tekstil (BBLH, 1998). Secara visual juga terlihat bahwa air limbah tekstil setelah diolah dengan MSL mengalami perubahan warna, yang sebelumnya berwarna hitam menjadi lebih jernih.

Tabel 3. Nilai BOD dan COD limbah cair tekstil sebelum dan setelah diolah menggunakan sistem MSL pada periode penyamplingan

\begin{tabular}{|c|c|c|c|c|}
\hline \multirow{2}{*}{$\begin{array}{l}\text { Periode } \\
\text { penyamplingan }\end{array}$} & \multicolumn{2}{|c|}{ BOD $\left(\mathrm{mg}^{-L^{-1}}\right)$} & \multicolumn{2}{|c|}{$\mathrm{COD}\left(\mathrm{mg} \cdot \mathrm{L}^{-1}\right)$} \\
\hline & Sebelum & Setelah & Sebelum & Setelah \\
\hline I & $1.214,29$ & 40,82 & 2.800 & 500 \\
\hline II & $1.316,33$ & 51,02 & 2.970 & 580 \\
\hline III & $1.071,43$ & 30,61 & 2.920 & 550 \\
\hline IV & $1.061,22$ & 30,61 & 2.860 & 540 \\
\hline V & $1.173,47$ & 40,82 & 2.940 & 590 \\
\hline VI & $1.153,06$ & 51,02 & 2.910 & 570 \\
\hline
\end{tabular}


Penurunan kadar zat organik dalam proses penjernihan air limbah terbagi dalam dua tahapan utama (Choliq, 1992 dan Waite et al., 1994). Pada tahapan awal, yaitu penurunan zat organik dalam bentuk partikel dan koloid untuk selanjutnya akan diikuti penurunan zat organik dalam bentuk larutan. Penurunan kadar zat organik dalam bentuk partikel dan koloid berlangsung relatif cepat dan lebih bersifat fisis yang bergantung pada karakteristik kimia dan fisika dari zat organik tersebut.

Mikroorganisme yang berperan dalam perombakan limbah cair industri tekstil dalam MSL terdiri dari kelompok bakteri, fungi, plankton, maupun protozoa yang hidup bersimbiosis mutualisme (saling menguntungkan) dan proses perombakan ini berlangsung secara berantai antara dua jenis mikroorganisme atau lebih. Menurut Sugiyanto(1994), mekanisme degradasi limbah oleh mikroorganisme terjadi secara sinergis antara alga (fitoplankton) dengan bakteri karena fitoplankton mengkonsumsi hasil metabolisme bakteri berupa zat hara, seperti $\mathrm{CO}_{2}$ dan $\mathrm{NH}_{3}$ hasil degradasi limbah oleh bakteri sedangkan fitoplankton akan menghasilkan oksigen yang akan dimanfaatkan oleh bakteri untuk kelangsungan hidupnya.

Proses dekomposisi air limbah yang terjadi dalam sistem MSL adalah proses aerobik maupun proses anaerobik. Proses aerobik terjadi pada lapisan zeolit dan pada bagian antar muka zeolit dengan lapisan tanah. Dekomposisi senyawa organik dari air limbah, fiksasi fosfat dan proses nitrifikasi dapat terjadi dalam daerah aerobik tersebut. Lapisan tanah merupakan tempat terjadinya proses anaerobik yang berperan penting dalam pemindahan nitrogen melalui proses denitrifikasi dan juga penting untuk transfer ion $\mathrm{Fe}^{2+}$ ke permukaan zeolit yang berperan penting dalam pemindahan fosfat (Luanmanee et al., 1999).

Menurut Tebbut (1977) di dalam kondisi anaerob terdapat dua kelompok jasad renik yaitu :

1. Kelompok pembentuk asam (non methanogenic) yang menghidrolisis zat organik menjadi senyawasenyawa sederhana (seperti asam asetat dan asam propionat).

2. Kelompok pembentuk gas (methanogenic) yang merubah asam yang terbentuk menjadi gas metana dan karbon dioksida serta ion nitrat.

Kemampuan MSL untuk mendekomposisi limbah pada proses anaerob ini dipengaruhi oleh pengaerasian. Menurut Tahir et al. (1997) pemberian aerasi yang cukup akan membantu pembentukan kondisi aerob, bagaimanapun setelah diaerasi selama beberapa waktu kondisi anaerob akan terbentuk dengan sendirinya dalam MSL.

Bahan organik akan dirombak secara aerobik di dalam kondisi aerob, setelah terjadi kontak dengan mikroorganisme yang terdapat dalam zona aerobik yaitu pada lapisan zeolit dan pada bagian antar muka zeolit dengan lapisan tanah. Menurut Soemantoyo (1991) proses perombakan bahan organik ini akan berlangsung terus sampai bahan organik dalam air limbah tersebut menjadi rendah dan pencampuran benarbenar merata, sehingga aktivitas mikroorganisme tersebut juga merata di semua tempat.

Menurut Pelczar dan Chan (1986) proses perombakan bahan organik limbah cair tekstil secara garis besar berupa proses perombakan bahan organik yang lebih kompleks yang terkandung di dalamnya melalui rangkaian reaksi kimia enzimatis yang dilakukan oleh mikroorganisme pengurai. Bahan organik kompleks dalam air limbah tekstil ini mula-mula diubah menjadi bentuk 
persenyawaan yang lebih sederhana. Tahap selanjutnya adalah perombakan persenyawaan sederhana tersebut menjadi $\mathrm{CO}_{2}, \mathrm{H}_{2} \mathrm{O}$ dan $\mathrm{NH}_{4}^{+}$.
Reaksi yang terjadi pada proses penguraian bahan organik baik secara aerob maupun anaerob ini menurut Hammer (1977) adalah sebagai berikut :

Aerob :

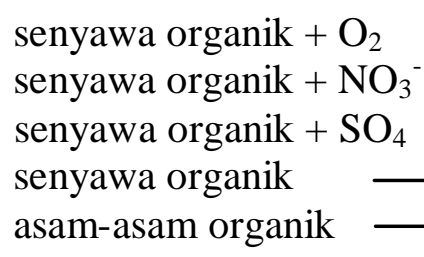

\section{KESIMPULAN}

1. Metode Multi Soil Layering (MSL) dapat digunakan sebagai metode alternatif dalam pengolahan limbah cair industri tekstil, yang ditunjukkan dengan penurunan nilai BOD dan COD setelah pengolahan dengan menggunakan metode MSL.

2. Kecepatan pengisian air limbah ke dalam sistem MSL untuk memperoleh penurunan nilai BOD dan COD limbah cair industri tekstil yang optimum adalah 320 L.m ${ }^{-2}$.hari 1 .

3. Efisiensi sistem MSL dalam penurunan nilai BOD dan COD limbah cair industri tekstil adalah $96,52 \%$ dan $80,87 \%$.

DAFTAR PUSTAKA

APHA. 1992. Standard Method for the Examination of Water and Wastewater, $18^{\text {th }}$ ed. American Public Health Association, Washington D.C.

Attanandana, T., B. Saitthiti, S. Thongpae, S.Kritapirom and $\mathrm{T}$. Wakatsuki. 2000. Wastewater Treatment Study using the MultiSoil Layering system, Paper Submitted on "Managing Water and Waste in the New Millenium", Johanesburg.
BBLH. 1998. Baku Mutu Limbah Cair bagi Kegiatan Industri di Propinsi Daerah Tingkat I Jawa Tengah. Setwilda Tk. I Jateng, Semarang.

Choliq, A.U. 1992. Pengolahan Limbah Organik dengan Sistem RBC, Proceeding Seminar Nasional Pengelolaan Lingkungan Tantangan Masa Depan. Jurusan Teknik Lingkungan ITB, Bandung.

Endang T. W. dan A. Yateman, 1994, Kajian Pemanfaatan Zeolit Dalam Penanganan Zat Warna Logam, Laporan Penelitian, Universitas Gajah Mada, Yogyakarta.

Luanmanee, S., B. Saitthiti, C. Panichajakul, and T. Wakatsuki. 2000. Efficiency of The Multi Soil Layering Systems with Various Organic Material Components on Domestic Wastewater Treatment. Paper Submitted on Managing Water and Waste in The New Millenium, Johannesburg.

Luanmanee, S., T. Attanandana, B. Saitthiti, C. Panichajakul, T. Wakatsuki, 1999. Efficiency of The Multi Soil Layering System With Various Urganic Material Components on Domestic Wastewater Treatment, Faculty of 
Life and Environmental Science, Shimane University, Matsue, Japan.

Pelczar, M.J. and E.C.S. Chan., 1986, Dasar-dasar Mikrobiologi. UI Press, Jakarta.

Pusat Sarana Pengendalian Dampak Lingkungan (PUSARPEDAL). 1996. Materi Ajar Pelatihan Analisis Kualitas Air dan Limbah Cair Tahap III. Pengendalian Dampak Lingkungan, Jakarta.

Soemantoyo, Rukmijati. 1991. Pengolahan Limbah Cair. Program Pascasarjana UI, Jakarta.

Sugiyanto, 1994, Pengolahan Biologis Limbah Cair, Makalah Workshop Pengolahan Limbah Cair. Kerjasama BAPEDAL dengan UNS Surakarta.

Tahir, Y. T. Harada and T. Wakatsuki. 1997. Enhancemen and Control of the Functions of soil Resources for Biogenic Wastewater Treatment by Multi Soil Layering Method. In Te Forth International Conference of East Federation of Soil Science Societies. "Soil Quality Management and AgroEcosystem Health”. p. 241-252. Cheju, Korea.
Tebbut, T.H.Y., 1977, Principles of Water Quality Control 2-nd Ed. University of Birmingham, England.

Wakatsuki, T., S. Luanmanee, T. Masunaga,T. Attanandana.2001. High Grade On-Site Treatment of Domestic Wastewater And Polluted River Water By MultiSoil Layering Method. Ecological Engineering, Elsevier.

Widyastuti, E., 1994, Limbah Industri di Perairan dan Pengolahannya Secara Aerobik, Majalah Ilmiah Unsoed No. 4 Th. XX, Purwokerto. 